ORIGINAL RESEARCH ARTICLE

\title{
MINERAL FERTLIZER AS AN ALTERNATIVE FERTILIZER IN INCREASING RICE YIELD IN TABANAN REGENCY
}

\author{
Indayati Lanya* and N. Netera Subadiyasa \\ Study Program of Agroecotechnology, Faculty of Agriculture, University of \\ Udayana, Denpasar 80232 Bali \\ * Corresponding author: indahnet@yahoo.co.id
}

Received : $7^{\text {th }}$ December 2016 $\mid$ Accepted : $9^{\text {th }}$ March 2017

\begin{abstract}
Production can be increased through improved harvest index genetic engineering, and the availability of nutrients in the soil. Ciherang rice production tests conducted over two years by toposekuen in Tabanan. First in five Subak, (Jangga, Bulung Daya, Andal Dewa, Lanyah1, and Perean) with 10 fertilizer treatments. The second year, five fertilization treatments in the two Subak (Petung dan Babahan). The study was conducted in randomized complete block design with three replications. Parameters observed included vegetative and generative growth, and yield of paddy field farming. Duncan`s test, with a confidence level of 5\% using the Costat program, and input output fertilization. Fertilization is very significant effect on rice production. The first year results, the highest rice production (9.33 tons ha-1) was achieved in a combination of fertilizer treatment (organic + NPK + mineral), can increase production $43.98 \%$. The second year of the highest rice production (11.878 tons $\left.\mathrm{ha}^{-1}\right)$ were achieved on the fertilization of NPM (100 $\mathrm{kg}$ urea $+100 \mathrm{~kg}$ Phonska ha $\left.{ }^{-1}\right)+$ organic fertilizer $\left(2.5\right.$ tons ha $\left.{ }^{-1}\right)+$ mineral fertilizer $(2.5$ tons $\mathrm{ha}^{-1}$ ), production increased $50.4 \%$. Organic fertilization received the lowest rice production $\left(5,420\right.$ to 8,940 tons $\left.\mathrm{ha}^{-1}\right)$, and the highest percentage of empty grain $(9.29 \%)$. Mineral fertilizers can reduce the use of chemical fertilizers and high-dose organic fertilizers. The increase in yield of paddy field farming compared to control for the treatment of organic fertilizer ( Rp 1.011 million ha $^{-1}$ ), NP ( Rp 6.416 million ha ${ }^{-1}$ ), NPK $\left(\right.$ Rp7.636 million ha $\left.{ }^{-1}\right)$, and NPM (Rp12.576 million ha $\left.{ }^{-1}\right)$.
\end{abstract}

Keywords: mineral, organic, NPK, fertilizer, rice production

\section{INTRODUCTION}

Central Bureau of Statistics (CBS) (2010) released the food needs of 238 million population of Indonesia requires \pm 34.986 ton ha $^{-1}$ million tons of rice, food supplies \pm 39.87 million tons. Bali Population 3,891,428 people (CBS, Bali Province, 2010) with food needs $147 \mathrm{~kg}$ of rice/capita/year (National Land Agency, 2008 ) is 572,040 tons of rice. Average production of paddy in Bali 5.6 tons of dry grain harvest $(\mathrm{DGH}) \mathrm{ha}^{-1}$, producing 840,465 tons of DGH ha $^{-1}(504,279$ tons of rice). In 2010, Bali is a deficit of 67,761 tons of rice food. 
Food security and sovereignty amino acids and protein synthesis in cells programs conducted with the goal of Achliya (Singh and Le John, 1975 in Payne, national food self-sufficiency. Various 1980) reported that $\mathrm{Ca}$ ions act as coupling agricultural development programs, or binding energy in the transport of amino including program Special Effort (UPSUS), aimed at increasing rice production, corn and soybean through improving irrigation and supporting facilities. This means that the increase in rice production should be done by all regions in Indonesia, including Bali. Average harvest index $(\mathrm{HI})<2$, with production still 5.5 tons $\mathrm{ha}^{-1}$ should be increased, minimal $\mathrm{HI} \geq 2$ and 6.5 tons of production. This can be achieved if sufficient irrigation channels and the provision of plant nutrients as needed by plants.

Macro nutrients (N, P, K, Ca, Mg and $\mathrm{S})$ and micro elements including $\mathrm{Zn}, \mathrm{Si}, \mathrm{Fe}$, and $\mathrm{Cu}$,) is needed by plants. Community Guidance Program a 70s, until now the government provides subsidized fertilizer NPK. $\mathrm{Ca}$ and $\mathrm{Mg}$ were never given subsidies. The need for $\mathrm{Ca}$ and $\mathrm{Mg}$ certainly need to be added to provide sufficient nutrients for plants and the impact on increased production (Lanya, 2001 and 2002).

Stanier, et al.,(1963). stated that $\mathrm{Ca}$ as a cofactor of several enzymes, such as proteinase, so it plays a role in the formation of protein compounds. The role of $\mathrm{Ca}$ ions are essential to the transport of acids with proton drive system. Different from $\mathrm{Mg}$, which serve as the core of chlorophyll, enzyme cofactor some energy binders and stabilizers acids and bases in the cell.

Magnesium is involved in enzymatic reactions through several mechanisms: (1) a bridge between the enzyme complex, and a substrate, such as the transfer of ATP; and a substrate, such as the transfer of ATP, dan (2) The element of $\mathrm{Mg}^{2+}$ reacting with pyrophosphate group from a molecule of ATP coenzyme form $\mathrm{Mg}$ ATP ${ }^{2-} . \mathrm{Mg}$ and ATP ${ }^{2-}$ is the active form of the enzyme (Mengel and Kirkby, 1979 in Lanya, 2002). $\mathrm{Ca}$ and $\mathrm{Mg}$ have significance in the air symbiotic $\mathrm{N}$ fixation. The addition of $\mathrm{CaSO} 4$ on peanut crops can increase the content of sucrose, fructose and glucose (Hale and Maynard 1977).

This research uses an interdisciplinary approach and gradual. The concept is, before the genetically improve crops, should begin with the improvement of soil nutrients to meet the nutrient needs of plants. So far, only the elements N, P, and $\mathrm{K}$ are added to the soil to increase production. Other macro elements such as $\mathrm{Ca}, \mathrm{Mg}$, and $\mathrm{S}$ is very rare to use as 
fertilizer. Therefore, through this research crop needs for $\mathrm{Ca}$ and $\mathrm{Mg}$ met from mineral fertilizer plus.

\section{MATERIALS AND METHODS}

The research was conducted in 2012 2013 in Tabanan as the the rice granary of Bali Province. Location of the research the first year in five of Subak (Jangga, Bulungdaya, Andaldewa, Lanyah1, and Perean) selected based toposekuen. The second year study conducted in three of Subak (Jangga, Petung and Babahan). Test fertilizing the first year using a randomized block design with 10 treatments and three replications. Fertilizer treatment consisted of: (1) $\mathrm{OO}$ (without fertilizer) as control; (2) NPK (urea fertilizer to 200 and $250 \mathrm{~kg}$ phonska ha ${ }^{-1}$ ); (3) 5 ton $\mathrm{BO}$ (organic fertilizers Bokashi 5 tones ha-1 ); (4) 5PM ( 5 tones mineral fertilizer $\mathrm{ha}^{-1)}$. Mineral fertilizer is a mixture of five tons of lime Bukit Jimbaran+200 kg+10 kg salt zinc phosphate ha ${ }^{-1}$; (5) NPK5BO (NPK fertilizer and 5 tones $\mathrm{ha}^{-1}$ Bokhasi); (6) NPK5PM (NPK fertilizer and 5 tons of fertilizer minerals ha ${ }^{-1}$ ); (7) NPK5BO5PM (NPK fertilizer +5 tons Bokhasi +5 tons of fertilizer minerals $\mathrm{ha}^{-1}$ ); (8) NPK2BO3PM (NPK fertilizer+ 2 tons Bokhasi +3 tons of mineral fertilizers $\left.\quad \mathrm{ha}^{-1}\right)$; NPK2BO2PM2PS (NPK fertilizer+ Bokhasi 2 tons, 2 tons of mineral fertilizers+ 2 tons of sand mountains; and (10) NPK3PM5PS (NPK fertilizer + Mineral fertilizers 3 tons +5 tons $\mathrm{ha}^{-1}$ mountain sand). Experimental plots measuring 3 x 5 meters.

The second year, testing of five different fertilizer treatments, consisting of: (1) $\mathrm{OO}$ (without fertilizer) as control; (2) BO (5 tons of organic fertilizer (Green Valley) and 1 ton of husk ha $\left.{ }^{-1}\right)$; (3) NP ( $200 \mathrm{~kg}$ urea and $150 \mathrm{~kg}$ SP36 ha ${ }^{-1}$ ); (4) NPK ( urea $200 \mathrm{~kg}+250 \mathrm{~kg}$ phonska ha-1); and (5) NPM ( urea $100 \mathrm{~kg}+100 \mathrm{~kg} \mathrm{SP36}$ +1 ton of husk +1 ton of organic fertilizer +2 tons of Jimbaran limestone +2 tons of sand mountains+200 $\mathrm{kg}$ salt $\mathrm{ha}^{-1)}$. Experimental plot size of 1 acre $\left(100 \mathrm{~m}^{2}\right)$, Ciherang rice varieties tested, a spacing of $20 \times 20 \mathrm{~cm}$, with an average of three seeds per hole. The observed parameters: average height, average number of seedlings of rice (stems / clump), rice yield ( $\mathrm{kg} \mathrm{GH}$ each plot), DGH 1000 grain weight (grams), and the average percentage of empty grain (\%). The observed data or measurement of these parameters was analyzed statistically, using analysis of variance (ANOVA) LSD 0:05, and the least significant difference (Duncan's Multiple Range Test) using Costat program. 


\section{RESULTS AND DISCUSSION}

Bulungdaya Subak experienced a rat attacks, Andaldewa Subak experienced a water shortages and stem borers attack and tungro, so that production is not optimal. Results of analysis of variance ANOVA showed high places and fertilizer treatment effect on vegetative and generative production. The complete data relationships between different fertilization treatment on the number of productive tillers and rice production of dgh is presented in Figure 1 and Figure 2.

Research data on the relationship between fertilizer treatment of vegetative and generative production of rice crops in Petung Subak and Babahan Subak listed in Figure 3 and Figure 4. Figure 3 is a graph of fertilization treatment with vegetative growth (the average height of the plants and the number of productive tillers).
Figure 4 is a graph of the relationship between fertilizer treatment with rice production (weight of 1000 grains and the percentage of empty grain). Results of effects of fertilization on the main factors of high places and DGH rice field Petung Subak (275 m asl) and Babahan Subak (495 m asl) (Figure 5).

The effect of fertilization on rice production in five Subak obtained results: high places and fertilizer treatment significantly affected production of rice field Ciherang varieties. The higher than sea level, the lower the height of plants and the fewer the number of productive tillers and the lower production. Water availability is very significant effect on rice production in the dry season.

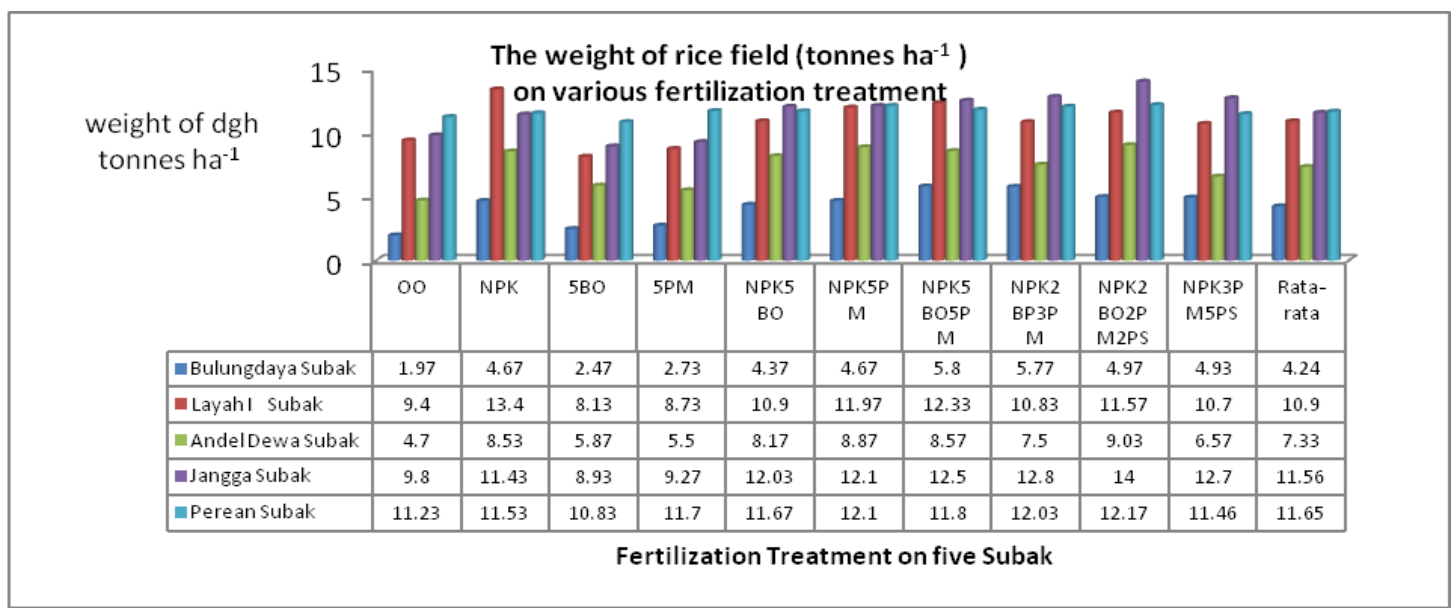

Fig. 1.Effect of fertilization on total Productive tillers in five Subak at Tabanan Regency 


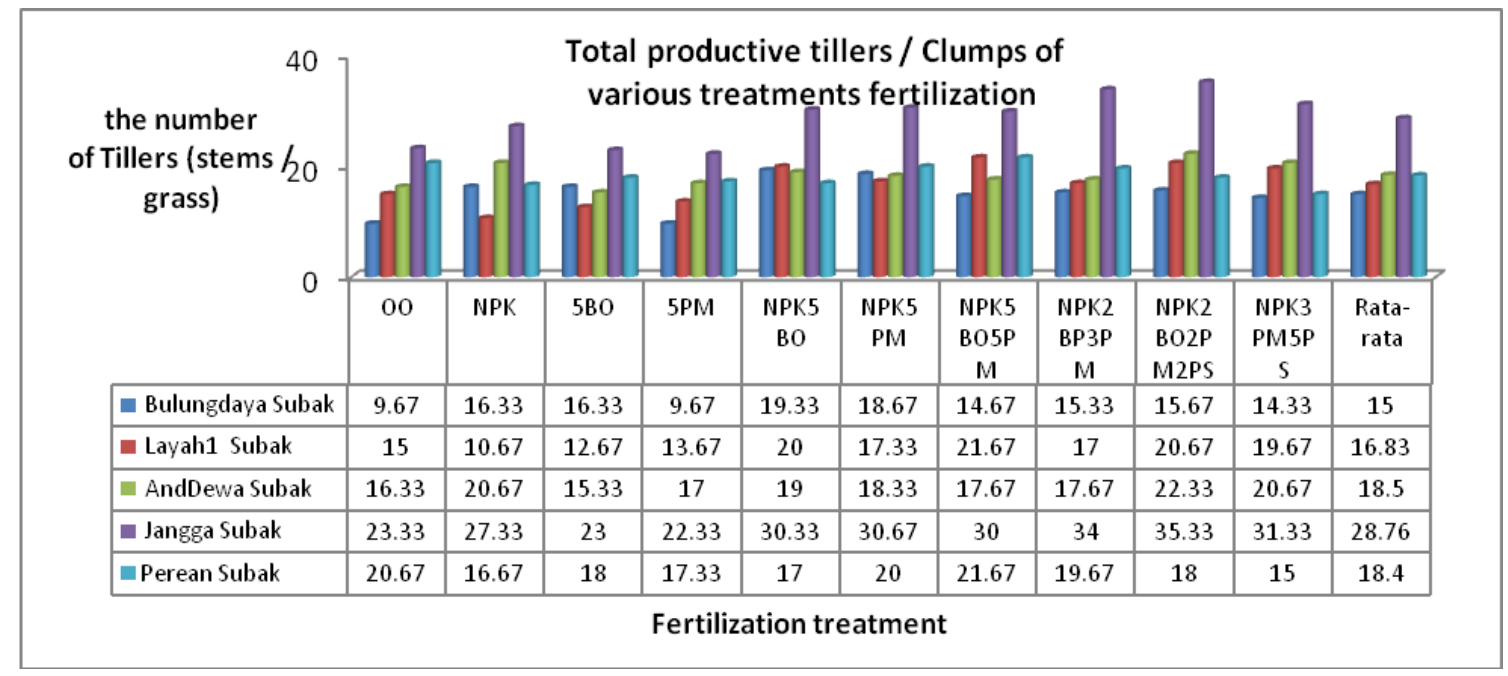

Fig. 2. Effect of fertilization on rice production weight of paddy field in five Subak at Tabanan Regency.


Fig. 3. The data of research results relationship between fertilization treatment with the production of rice field (plant high and total productive tillers) in Petung Subak dan Babahan Subak, Tabanan Regency, Bali

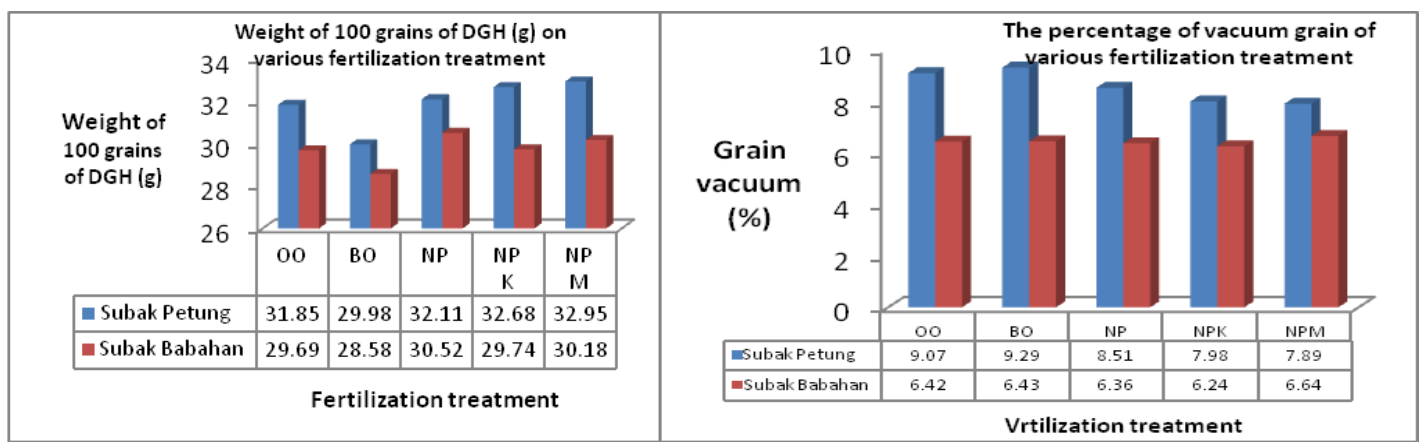

Fig. 4. The data of research results relationship between fertilization treatment with rice production (1000 grain weight of $\mathrm{dgh}$ and the percentage of empty grain) in Petung Subak and Babahan Subak, Tabanan, Bali 




Fig. 5. Effect of fertilization on production dgh rice field Petung Subak and Babahan Subak, Tabanan Bali (anlysis, 2016)

Plant height and achieved the highest productive tillers at fertilization combination of NPK fertilizer packages + 2 tons of organic matter $\mathrm{ha}^{-1}+2$ tons of limestone/ ha +2 tons $\mathrm{ha}^{-1}$ sand $+200 \mathrm{~kg}$ salt $\left.\mathrm{ha}^{-1}\right)$.

Average plant height ranged between 86.6 - $105.3 \mathrm{~cm}$ lower than its description $(107-115 \mathrm{~cm})$. The highest rice crop (105.3 $\mathrm{cm}$ ) in Subak Jangga are located in coastal areas and the lowest $(60.4 \mathrm{~cm})$ in Subak Perean located $420 \mathrm{~m}$ asl. The highest number of productive tillers (28 stems / clump) in Subak Jangga, and the lowest (18 stems / clump) in Subak Perean. Data discrepancies are caused by several factors, including climatic factors, such as temperature and duration of sunshine. The rice field located in the downstream area (lowland) will get a higher temperature and sun longer than the upstream areas.
Temperature and radiation are much more influence on the process of photosynthesis, the longer, vegetative growth, and generative getting better. Fertilization treatment very significant effect on rice production of dry grain harvest. While fertilization treatment against the grain weight of 1000 , and the percentage of empty grain non significant.

The average number of tillers highest production (35 stems / clump) in Subak Jangga achieved by treatment (NPK +2 tons $\mathrm{BO}, 2$ tons $\mathrm{PM}+2 \mathrm{PS})$ or a combination of chemical fertilizer + organic fertilizer + mineral fertilizers). Followed by a combination of NPK $+\mathrm{OF}$ $+\mathrm{MF})$. This is understood because the fertilizer containing macro nutrients required by plants, such as nutrients $\mathrm{N}, \mathrm{P}$, $\mathrm{K}$ from NPK fertilizer and organic 
fertilizer, nutrients $\mathrm{Ca}$, and $\mathrm{Mg}$ from mineral fertilizers.

The average rice field production from various fertilization treatment (Figure 2). The main factor fertilization very significant effect on rice production, except in Subak Perean. Average production rice field lowest (2,827 ton / ha) in Bulungdaya Subak and Andaldewa Subak (4.887 tonnes $\mathrm{ha}^{-1}$ ), the second this Subak rat infested by pests. The production in Lanyah 1 Subak 7.267 tonnes ha-1, Jangga Subak 7.707 tonnes ha $^{-1}$, and Perean Subak 7.767 tonnes ha ${ }^{-1}$ ). The average production from the third Subak is 7,580 tonnes ha- ${ }^{-1}$.

The combination of fertilizer NPK + $\mathrm{BO}+\mathrm{PM}+\mathrm{PS}$ get the highest production compared with other treatments throughout Subak. The highest production (14 kg / 15 $\mathrm{m}^{2}$ ), or 9.333 tonnes $\mathrm{ha}^{-1}$ ) and in Perean Subak (8.113 tonnes $\left.\mathrm{ha}^{-1}\right)$. These data indicate that high production is needed to obtain a combination of chemical fertilizer + organic + mineral. The combination of these fertilizers contain nutrients more complete than single fertilizer. The results also show that the use of NPK fertilizer is still needed to increase production. The combination of a half dose of fertilizer (NPK + mineral fertilizers) generally obtain higher yields compared with the combination NPK fertilizer with organic fertilizer and organic fertilizer single. That is to increase rice production required macro nutrients $\mathrm{N}, \mathrm{P}, \mathrm{K}, \mathrm{Ca}, \mathrm{Mg}$, and fertilizer organic low doses. To increase the production $(20-50 \%)$ it is recommended the use of half-doses of fertilizer package + mineral Fertilizer.

Dose of organic fertilizer were very much (5 tons $\mathrm{ha}^{-1}$ ), the availability of chemical fertilizers (NPK) that is often rare in the growing season could be overcome with the use of mineral fertilizers at half the dose of NPK fertilizer dose and half dose of organic fertilizer. This can reduce the environmental pollution caused by use of a high dose of organic fertilizer and chemical fertilizer. The average the lowest production of organic fertilizers results, is caused by low nutrient, available phosphorus content $(\mathrm{P})$ which functions to generative growth. For that when using organic fertilizers to increase production, it must be added with a half dose of chemical and half a dose of mineral fertilizers.

The use of urea and Phonska fertilizer still needed to increase the rice field production, for obtaining higher production of organic fertilizers throughout the study site. The production can be increased $(42.857 \%)$ by adding organic fertilizer low dose $\left(2.5\right.$ tons $\left.\mathrm{ha}^{-1}\right)$ and mineral fertilizers dose of 2.5 tons $\mathrm{ha}^{-1}$ in addition to the half-dose package (100 $\mathrm{kg}$ urea $+100 \mathrm{~kg}$ Phonska). This means 
that the use of mineral fertilizers could reduce the use of disposable doses of chemical fertilizers (urea and Phonska) and organic fertilizers which require high doses.

Increased productivity of rice fields is done through the provision of fertilizers (NPK) as fertilizer package (200 kg urea + $250 \mathrm{~kg}$ phonska ha ${ }^{-1}$ ) and the addition of natural fertilizers (lime Jimbaran hill, salt and sand mountains Agung), and their combinations to meet the needs of nutrients required by plants.), and their combinations to meet the needs of nutrients required by plants. The addition of fertilizer is higly signivicance increased vegetative growth (plant height and number of productive tillers).

The combination of artificial fertilizers (NPK), organic fertilizer (Bokashi) and natural fertilizers (mineral) can increase the average rice production of $79.4 \%$, the addition sand so it increases the production of DGH In contrast to a single organic fertilizer, production is equal to or lower than the control and the percentage of empty grain is higher than other treatments. Therefore, a single organic fertilizers are not recommended, due to low production. To obtain the high production, the organic fertilization should be combined with chemical fertilizer and mineral fertilizers. Production of rice at four research sites, except in Subak Bulungdaya ranged from 4.89- 9.33 tons DGH ha ${ }^{-1}$. The average production of 6,95 tons $\mathrm{ha}^{-1}$. Bulungdaya Subak not included in computing the average production because of a lack of water and stem borer attack and of the disease.

Farmers' income increased between $20 \%$ to $79 \%\left(1.39-5.45\right.$ tonns dgh $\mathrm{ha}^{-1}$.) equivalent to $\mathrm{Rp} 3.475$ million - $\mathrm{Rp}$ 13.625 million ha $^{-1}$ every harvest ( RP 34 750- Rp 136000 acre $^{-1}$ every harvest). Based on the effect of fertilizer to the increase in production and the calculation of economic value, dosages of $200 \mathrm{~kg}+$ $250 \mathrm{~kg}$ urea phonska combined with 2 tons ha $^{-1}$ bokhasi +2 tonns ha ${ }^{-1}$ of mineral fertilizers +2 tons $\mathrm{ha}^{-1}$ of sand provide maximum production results and an the optimal dosage for increasing rice production.

Research in the second year is based on the research of the first year, which is still necessary to increase production of NPK fertilizer derived from the urea and phonska (fertilizer package). The use of organic fertilizer production obtaining is lower than other fertilization treatment. Mineral fertilizers to increase production when combined with a half dose of fertilizer package, and half organic fertilizer. Results of statistical analysis show that the main effect (high spot and 
fertilizer treatment) very significant effect on rice production of DGH. While the high place the fertilizer treatment there is no interaction. These results are consistent with the results of the first year of the study, namely: production is highly influenced by the high place and fertilizer treatment. The higher the location, the lower production. Average production of paddy rice at various fertilization treatment is 9.736 tons $\mathrm{ha}^{-1}$. Petung Subak). Babakan Subak significantly different from the with an average production of 8.654 tons $\mathrm{ha}^{-1}$. These results are consistent with studies in the first year of the five Subak, that the production affected by the high place.

Real difference test the influence of fertilization on the production obtaining records: the highest production (10.633 tons $\mathrm{ha}^{-1}$ ) were obtained from the application of $\mathrm{N}$ and $\mathrm{P}$ fertilizer are combined with mineral fertilizers (NPM) an increase of $38.70 \%$, followed by NPK fertilization (9.855 tons $\left.\mathrm{ha}^{-1}\right)$, an increase of $28.55 \%, \mathrm{NP}\left(9.304\right.$ tons $\left.\mathrm{ha}^{-1}\right)$ an increase of $21.36 \%$, lowest of organic fertilizers (8.516 tons $\left.\mathrm{ha}^{-1}\right)$, an increase of $11.08 \%$. The analysis also shows that organic fertilization is not significantly different from controls. Instead the use of fertilizers NPM very significantly different from the control and control different from NP fertilizer.
Production of rice field of NPK fertilization results are not significantly different from the NP fertilization. This means that the nutrients $\mathrm{K}$ is not necessary to increase rice production in Petung and Babahan Subak. Increased production is obtained from the addition of mineral fertilizers in fertilizer NP (NPM). Assumptions of organic fertilizers 5 tons $\mathrm{ha}^{-1}$ is not sufficient nutrients rice fields. Low and slow nutrient content available is a major obstacle to the use of of organic fertilizers increase rice production.

The research an increase in rice field production for two years in seven Subak data showed that: mineral fertilization are combined with NP fertilizers obtained the highest results compared with using a single fertilizer (NPK, PO, PM). Potassium fertilizer is not needed because there was no significantly difference between the treatment of NP and NPK. This is caused the content of $\mathrm{K}$ element in soils in the study site is very high, which comes from irrigation water sourced from springs slopes of Mount Batukaru Tabanan.

Results the analysis of granting farming systems fertilizer treatment, used assumptions: dgh is equivalent to $85 \%$ of milled rice and prices at the time of the study. Price MR $=\operatorname{Rp} 4500.00 \mathrm{~kg}^{-1}$, the price of fertilizer: urea $\operatorname{Rp} 2000.00 \mathrm{~kg}^{-1}$, SP36 Rp $3000.00 \quad \mathrm{~kg}^{-1}$,Phonska Rp $3000.00 \mathrm{~kg}^{-1}$; Jimbaran lime stone $\mathrm{Rp}$ 
$350,00 \mathrm{~kg}^{-1}$, of organic fertilizers (Green Valley) $\mathrm{Rp} 1000.00 \mathrm{~kg}^{-1}$ sand mountains Rp $50.00 \mathrm{~kg}^{-1}$, salt Rp $1000.00 \mathrm{~kg}^{-1}$.

Not including ground rent, labor costs and taxes, the rest of the farm per ha in Babahan Subak without fertilizer (OF) is Rp 28, 438 million, the treatment PO, NP, NPK and NPM consecutive Rp 25, 951 million, 32.954 million, 35.250 million and 34.493 million. This means an increase of net income of farmers was highest in NPK, which amounted to Rp 6.812 million per ha which is not significantly different from NPM treatment of Rp 6.055 million, The use of organic fertilizers decrease of net income of farmers amounted to $\mathrm{Rp} 2.487$ $\mathrm{ha}^{-1}$ every harvest.

Calculation as above, net income of farmers per hectare in Petung Subak without fertilizer (OO) is $\mathrm{Rp} 30.206$ million. Farming Systems organic fertilizer treatment, NP, NPK and NPK each hectare successively USD 29.195 million, USD 36.622 million, Rp 37.842 million and $\mathrm{Rp} 42.782$ million. Organic fertilization, turns down the remainder of farm produce amounting to $\mathrm{Rp} 1,011$ million $\mathrm{ha}^{-1}$. The increase in net income of farmers occurred in the treatment of NP, NPK and NPM successively Rp 6.416 million, Rp 7.636 million and Rp12.576 million $\mathrm{ha}^{-1}$.

\section{ACKNOWLEDGEMENT}

Gratitude to the Minister of Education and Culture of the Republic of Indonesia, the Minister of Agriculture and Minister of Cooperatives of the Republic of Indonesia that has provided research grants. The Rector of Udayana Univeritas and $\mathrm{Mr}$. Dean of the Faculty of Agriculture which provide our research facility we say thank you. As well as to colleagues who helped research we say thank you.

\section{REFERENCES}

Community Assistance Program Team Tani, Bali area. (2000). Community Service Organization. Annual Report, Community Assistance Program Farmers Towards Food Security, region Bali. Institutions Community Services Udayana University. Denpasar.

Hale, M. G. (1978). Calsium Consentration and the Exudation of Sugar from Pegs and Fruits of Exenic Peanut Plants. Soil Biol. \& Biochem. 10 (1) : 67-69.

Lanya, I. (2001). Increased productivity and quality of melon fruit, and agribusiness, through the addition of mineral fertilizers. Agritrop 20 (2) 86-90.

Lanya, I. (2002). Evaluation of Rice Fertilization Recommendations for Specific Location Region of Agricultural Extension Center. Bali Province. Agritrop 21 (2) 57-63.

Lanya, I., Subadiyasa, N. N., Sardiana, K., \& Ratna Adi, G. P. (2015). Numerical clasification, Subak zoning and land transfer function paddy field in Province of Bali on 
Remote Sensing and GIS. Procedia

Environmental Sciences. 24 : 47-55.

National Land Agency. (2008). Final

Report Balance Rice Fields Bali

Island. National Land Agency.

Payne, J. W. (1980). Microorganism and

Nitrogen Source Transport and

Utilization of Amino Acid,

Peptides, Protein, and Related

Substrates. John Wiley and Sons,

Toronto

Stanier, R. Y., Doudoroff, M. J., \& Adelberg, E. A. (1963). The Microbial Word. Second Ed. Prentice-Hall, New York. 682 p.

The Central Bureau of Statistics of Bali Province. (2010). The results of the population census of 2010. Data on aggregate each district / city of Bali province. The Central Bureau of Statistics of Bali Province. Denpasar 